\title{
Brain and liver iron accumulation in aceruloplasminemia
}

Figure 1 Brain MRI
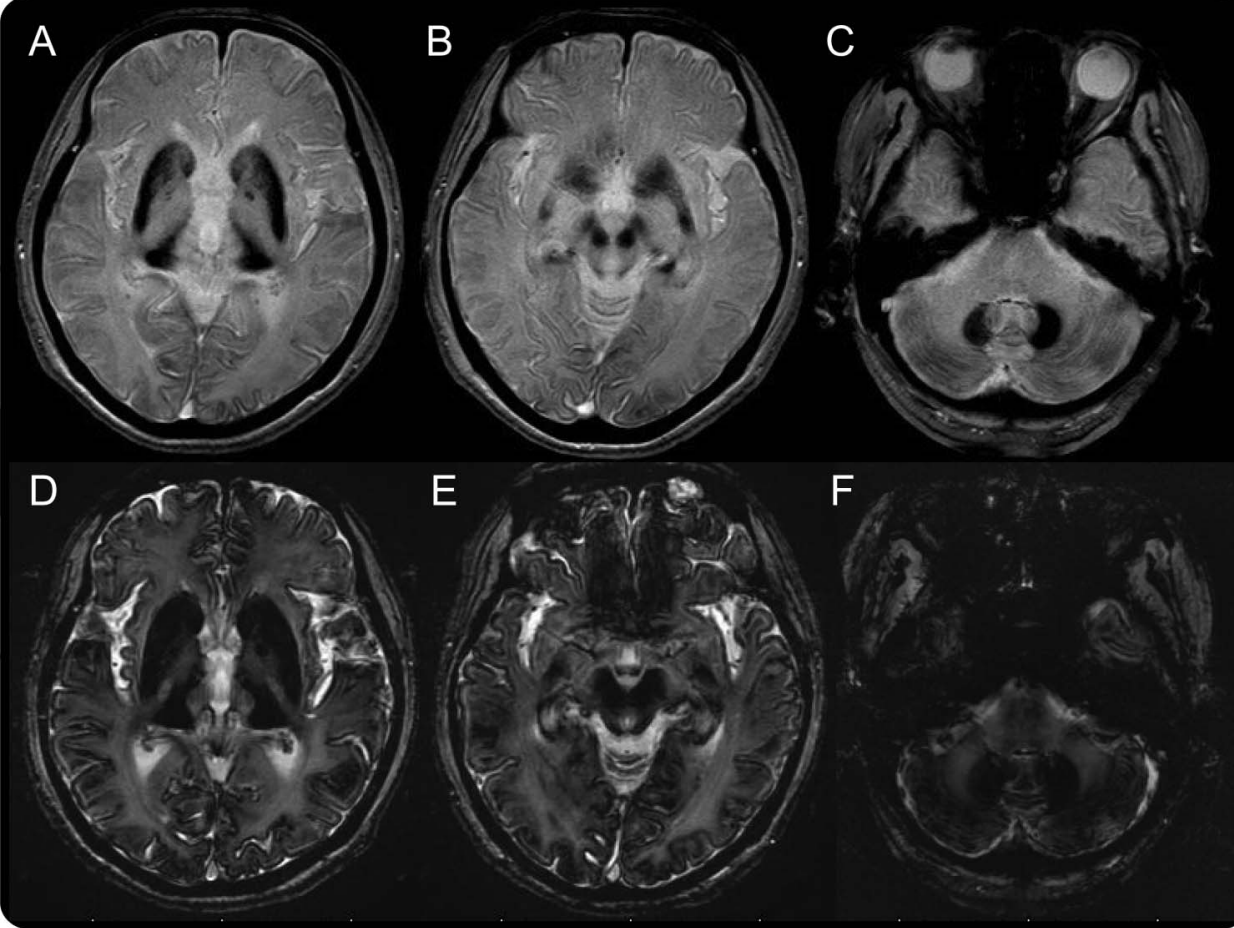

E

F
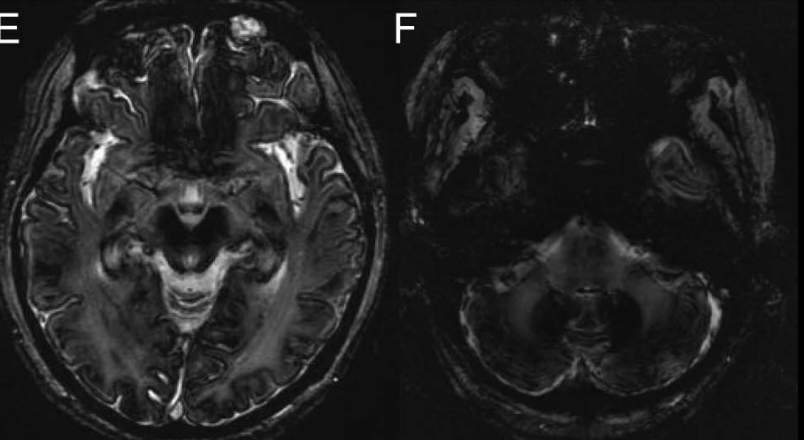

1.5T (A-C) and 3T (D-F) T2*-weighted MRI shows hypointensity in the striatum, thalamus $(A, D)$, red nucleus $(B, E)$, and dentate nucleus $(\mathrm{C}, \mathrm{F})$, and on the brain surface $(\mathrm{A}-\mathrm{F})$.

A 68-year-old woman with diabetes, anemia, and retinal degeneration developed mild cognitive impairment and subtle gait ataxia. Her parents were nonconsanguineous, and her sister had diabetes. T2*-weighted brain MRI showed symmetric hypointensity in the striatum, thalamus, red nucleus, and dentate nucleus, and on the brain surface, more prominently on high-field imaging (figure 1). Liver MRI demonstrated marked signal attenuation (figure 2). Serum ceruloplasmin was undetectable, and genetic testing revealed a homozygous mutation (p.W858X)

Figure 2 Liver MRI

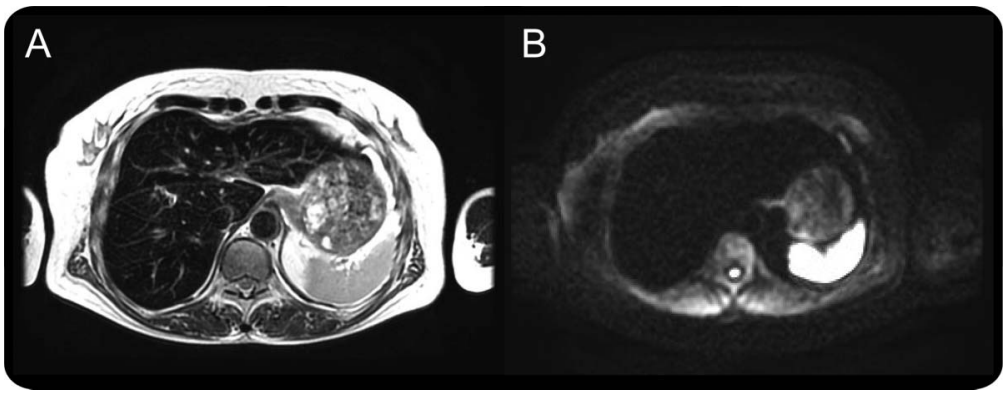

1.5T T2-weighted $(\mathrm{A})$ and diffusion-weighted $\left(\mathrm{b}=800\right.$ seconds $\left./ \mathrm{mm}^{2} ; \mathrm{B}\right)$ liver MRI. 
in the ceruloplasmin gene, confirming the diagnosis of aceruloplasminemia. ${ }^{1}$ This case highlights the importance of T2*-weighted MRI in diagnosing aceruloplasminemia, even in patients with minimal neurologic symptoms.

Koji Fujita, MD, Yusuke Osaki, MD, Masafumi Harada, MD, Satoshi Kono, MD, Hiroaki Miyajima, MD, Yuishin Izumi, MD, Ryuji Kaji, MD

From the Department of Clinical Neuroscience (K.F., Y.O., Y.I., R.K.) and Radiology (M.H.), Institute of Health Biosciences, The University of Tokushima Graduate School, Tokushima, Japan; and the First Department of Medicine (S.K., H.M.), Hamamatsu University School of Medicine, Hamamatsu, Japan.

Author contributions: Dr. Fujita: design/conceptualization of the study, acquisition of data, analysis/interpretation of the data, drafting/revising the manuscript. Dr. Osaki: acquisition of data, drafting/revising the manuscript. Dr. Harada: acquisition of data, analysis/interpretation of the data, drafting/revising the manuscript. Dr. Kono: acquisition of data, analysis/interpretation of the data, drafting/revising the manuscript. Dr. Miyajima: acquisition of data, analysis/interpretation of the data, drafting/revising the manuscript. Dr. Izumi: drafting/revising the manuscript. Dr. Kaji: drafting/revising the manuscript.

Study funding: No targeted funding reported.

Disclosures: The authors report no disclosures relevant to the manuscript. Go to Neurology.org for full disclosures.

Correspondence to Dr. Fujita: kof@clin.med.tokushima-u.ac.jp

1. Kono S. Aceruloplasminemia. Curr Drug Targets 2012;13:1190-1199.

\section{NeuroImages Are Free at www.neurology.org!}

All Neurology ${ }^{\circledR}$ NeuroImages can now be freely accessed on the Neurology Web site. See them at www.neurology.org, where you can also sign up for journal email alerts and check out other online features, including the Resident \& Fellow section, Neurology: Clinical Practice, and the weekly Neurology Podcasts. 


\section{Neurology}

\section{Brain and liver iron accumulation in aceruloplasminemia \\ Koji Fujita, Yusuke Osaki, Masafumi Harada, et al. \\ Neurology 2013;81;2145-2146 \\ DOI 10.1212/01.wnl.0000437304.30227.bd}

This information is current as of December 9, 2013

\section{Updated Information \& Services}

\section{References}

Subspecialty Collections

Permissions \& Licensing

Reprints including high resolution figures, can be found at: http://n.neurology.org/content/81/24/2145.full

This article cites 1 articles, 0 of which you can access for free at: http://n.neurology.org/content/81/24/2145.full\#ref-list-1

This article, along with others on similar topics, appears in the following collection(s):

Endocrine

http://n.neurology.org/cgi/collection/endocrine

Gait disorders/ataxia

http://n.neurology.org/cgi/collection/gait_disorders_ataxia

Hematologic

http://n.neurology.org/cgi/collection/hematologic

MCI (mild cognitive impairment)

http://n.neurology.org/cgi/collection/mci_mild_cognitive_impairment MRI

http://n.neurology.org/cgi/collection/mri

Information about reproducing this article in parts (figures,tables) or in its entirety can be found online at:

http://www.neurology.org/about/about_the_journal\#permissions

Information about ordering reprints can be found online:

http://n.neurology.org/subscribers/advertise

Neurology ${ }^{\circledR}$ is the official journal of the American Academy of Neurology. Published continuously since 1951, it is now a weekly with 48 issues per year. Copyright (O) 2013 American Academy of Neurology. All rights reserved. Print ISSN: 0028-3878. Online ISSN: 1526-632X.

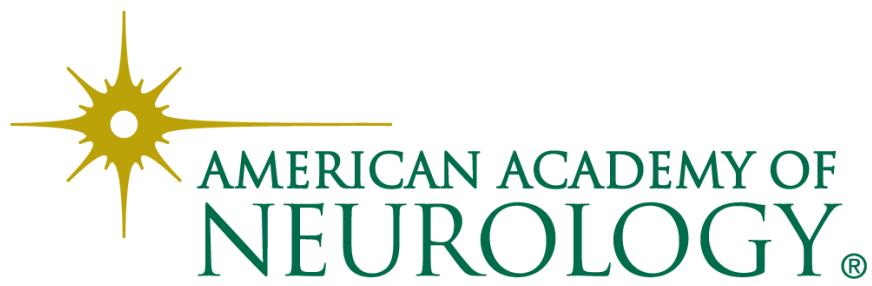

